\title{
Learning Application of Multimedia-Based-Computer Network Using Computer Assisted Instruction Method
}

\author{
Janner Simarmata ${ }^{1 *}$, Tonni Limbong ${ }^{2}$, Efendi Napitupulu ${ }^{1}$, S Sriadhi ${ }^{1}$, A R S Tambunan ${ }^{1}$, Enny Keristiana \\ Sinaga $^{1}$, Suhairiani ${ }^{1}$, C G G T Sibarani ${ }^{1}$, Maulana Arafat Lubis ${ }^{3}$, Muhammad Irwan Padli Nasution ${ }^{4}$, Agung \\ ${ }^{1}$ Universitas Negeri Medan, Medan, Indonesia \\ ${ }^{2}$ Universitas Katolik Santo Thomas, Medan, Indonesia \\ ${ }^{3}$ IAIN Padangsidimpuan, Indonesia \\ ${ }^{4}$ Universitas Islam Negeri Sumatera Utara,Medan, Indonesia \\ ${ }^{5}$ Bina Nusantara Institute of Creative Technology Malang, Malang, Indonesia \\ ${ }^{6}$ Universitas Wijaya Kusuma Surabaya, Surabaya, Indonesia \\ ${ }^{7}$ Universitas Graha Nusantara Padangsidimpuan, Indonesia \\ ${ }^{8}$ Universitas Islam Sumatera Utara, Medan, Indonesia \\ ${ }^{9}$ STMIK Royal Kisaran, Indonesia \\ ${ }^{10}$ STMIK Budi Darma, Medan, Indonesia \\ *Corresponding author E-mail: jannersimarmata@ unimed.ac.id
} Purnomo $^{5}$, Fatkul Anam ${ }^{6}$, Fauziah Nasution ${ }^{7}$, Desi Novita ${ }^{8}$, Satria Yudha Prayogi ${ }^{8}$, Juna Eska ${ }^{9}$, Riswan Limbong ${ }^{10}$

\begin{abstract}
In conventional learning, teachers frequently face difficulties to deliver their materials due to limited time and practical materials in teaching network computer. Conventional teaching process, especially practical materials, has still not yet been optimal. Thus, computer and multimedia based learning is required to help the students. Besides it can reduce costs in practical materials procurement, the students can absorb the given knowledge well without thinking of the costs to buy the practical materials. Computer Assisted Instruction Method can present the learning using various media either by picture or video that can assist the effective learning process and simplify the students to manage the learning speed since it is combined with the multimedia. By doing this, the students can practice the lesson materials, study whenever and wherever they want. Compuer learning application prioritize user interface, user friendly, which can make the students be diligent and passionate in learning.
\end{abstract}

Keywords: Learning Application, Multimedia, Computer Network, Computer Assisted Instruction

\section{Introduction}

In conventional learning process, the teachers frequently face difficulties to deliver the materials due to the limited time. The weakness of the current learning system is lack of interaction between the students and the teachers, even among the students [1]. The students tend to ignore the academic and social aspects so that they have less motivation [2]. Learning process is still less optimal if using the inappropriate learning media and method [3]-[6]. The appropriate learning method will determine whether the students can absorb well the given knowledge or not. Computer network is the connection of two or more computers to gain information and communication as much as possible such as the group of computers, printers and other equipment which are connected in one unit. Information and data move by or without the cabels so that the computer network user can exchange the document or data, print at the same printers, and share hardware/software which is connected to the network. Each computer, printer or peripheral connected to the network is called node. A computer network can have two, dozens, thousands, or even millions of node.
In computer network lesson, the students are hoped to be able to build and manage the network continuosly by understanding the basic principles of network computer system in developing the Local Area Network (LAN) and Wide Area Network (WAN). Applying the Computer Assisted Instruction method and multimedia in this learning, of course, gives the learning format gradually and detailed [7]. The students or user can understand the lesson topic overall. In part of model and exercises in Computer Assisted Instruction, it can help the students or user to know how understand they are in the available materials [8] [9]. Every user will try to get the best score in learning.

The significance of the study is to introduce and supervise the students about the network computer. In addition, it can stimulate the students' interest since it is equipped with the multimedia that can make the learning process more interesting.

\section{Research Method}

The research method used in this application creation is System Development Life Cycle (SDLC). This method is a series activities conducted by the professional and information system user 
to develop and implement the application [10][11]. The phases of SDLC approach are:

a. System plan phase, in this phase, data collection is conducted, and then determines how the system can solve the existing problems.

b. Analysis phase, this analysis phase is done by analyzing the system required to determine the criteria of lecturer assistant such as data analysis, problem identification, and system analysis.

c. Design phase, It is conducted by two stages: (1) Data base design. This design is conducted by creating the table and data structures related to the database. (2) System design in general. At this phase, it is organized the plan of flowchart system procedures in data flow diagram and flowchart system.

d. Implementation phase, It is conducted after the design phase has been completely done. Then, the creation stage is done in programming language. The programming language used is PHP and HTML, while MySQL becomes the database.

e. Trials phase, Trials system is a test conducted after the system creation has been done by having the experiment on the user interface.

f. Usage phase (Maintenance system phase), The usage phase is a phase where the system has been designed and then successfully through the trials phase and then it can be used.

\section{Result \& Discussion}

\subsection{Analysis of Computer Network Learning}

The results of the computer network learning based on the analysis are as follows:

1. In learning process, there are two ways of preparation:

a. Teachers' preparation before conducting the teaching and learning process, there are some meetings in teaching and learning process:

1. Meeting I

- The teachers give guidance and referrals to the students on how to use learning media

- The teachers deliver the topics that will be discussed

- The learning starts with introducing the tools and devices

2. Meeting II

- $\quad$ The teachers give the examples of the tools and devices in pictures

- The students understand and go deep into the types of devices, tools and software of computer network.

- $\quad$ The teachers evaluate the students by asking the types, functions, and steps of building the computer network

3. Meeting III

- The teachers give the test based on the materials of computer network

- The students answer the tests by learning media

b. Some steps in the students' preparation in teaching and learning process:

1. Understand

In this process, the students is aimed to understand the topics given by the teachers, the students can understand and comprehend the learning aims of computer network generally.

2. Listen

In this process, the students are aimed to listen the topic content given by the teachers so that the students can understand the learning.
3. Answer

In the process of answering, the students are aimed to answer the topic content given by the teachers. In this process, the students answer the tests in multiple choice format.

2. The application of Computer Assisted Instruction method in subject matter which is divided into 4 parts, namely:

a. Tutorial

In this tutorial process, the teachers describe the definition of computer network; There are two tutorial videos, namely, tutorial video on the use of tools and ways to set the computer network. In each video, there are two techniques of straight and cross cabeling.

b. Material

In this learning, the materials in discussion of the title content given to the students. In this learning discussion, materials are divided into two, namely:

1. Cabling System

This material contains the guidelines about the tools required and how to use, the definition of RJ45 cabling in the form of Straight and Cross

2. Installation and Network Setting

This material contains on how to do with the IP setting each unit and giving and sharing IP among servers and client in the concept of LAN

c. Exercises

In this learning, exercises are divided into ten questions and in a multiple choice format

d. Game

In this learning, there is a Game Puzzle (arrange pictures), where the students hae to complete the picture arrangement appropriately.

3. In the application plan, the learning consists of some pages/form of application:

a. Page

Page is the application content that cun run that is the Media Application of basic computer network of introductory learning

b. Main Page

This page contains of home navigation, tutorial, material, exercises, game

c. Home page

This page contains of guidelines or definition of computer network

d. Tutorial Page

e. This page contains of the guidelines for tools introduction, software, and the ways to set the computer network in the form of video.

f. Material Page

This page contains material guides that can be learned about the discussion according to the title page that is the introduction of tools, software, and IP configuration techniques.

g. Exercises Page

This page contains the discussion items contained in the material in the form of multiple choice.

h. Game Page

This page contains the puzzle to arrange the random pictures

\subsection{The Application of CAI Method}

The learning using Computer Assisted Instruction (CAI) evolves with the development of computers and technology [12]. The use of Computer Assisted Instruction (CAI) method in the basic network learning system can be made in several models, namely:

1. Tutorial

The material presented in the tutorial is the subject matter that has been discussed where the material presented in this 
tutorial will be in the form of video and animation, with some menu selection buttons so that the learners can choose the easy material and can repeat the material that has not been understood. This material is made in text and document

2. Exercise (Drill)

The drill model is an exercise-based learning technique that aims to provide learning experiences to learners through the provision of training questions to test the skills of learners through the speed of completing the training provided by the system, the user is expected to answer questions correctly and quickly, and the computer will provide feedback on answers, in the form of true or false messages. After all the problems are done, the computer will give the message the right number of questions from the number of questions that have been done by the user.

3. Simulation

The simulation in this basic networking study features video simulation of the network using 2 pieces of switch / Hub, sometimes the user has difficulty in determining the criteria. Therefore the authors make the design of this simulation application that will display a network simulation video using 2 pieces of switch / Hub in the form of animation simulation.

4. Games

The game designed is a simple educational game that is how to understand the basic network in solving the problem in the game puzzle, which is expected to eliminate boredom in playing a simple puzzle.

\subsection{Implementation}

Implementation is the stage done after completing the application design. In this implementation, preparation is conducted on the required application tools.

1. Display Main Menu

In this view there is a second display that is displayed when the application is run and will display some menu options for the user are: tutorials, simulations, exercises, games.

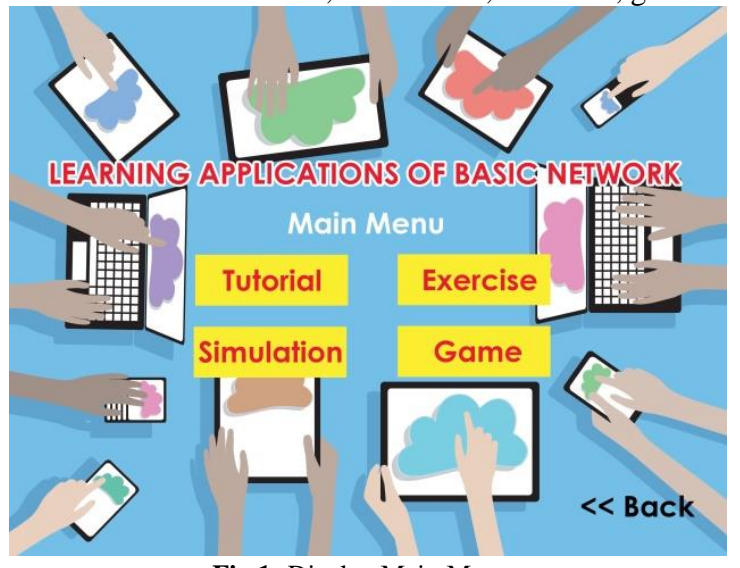

Fig.1: Display Main Menu

2. Display Tutorial Menu

In the tutorial view contains sub menus of each lesson of basic network system, where each sub displays the basic network system learning materials.

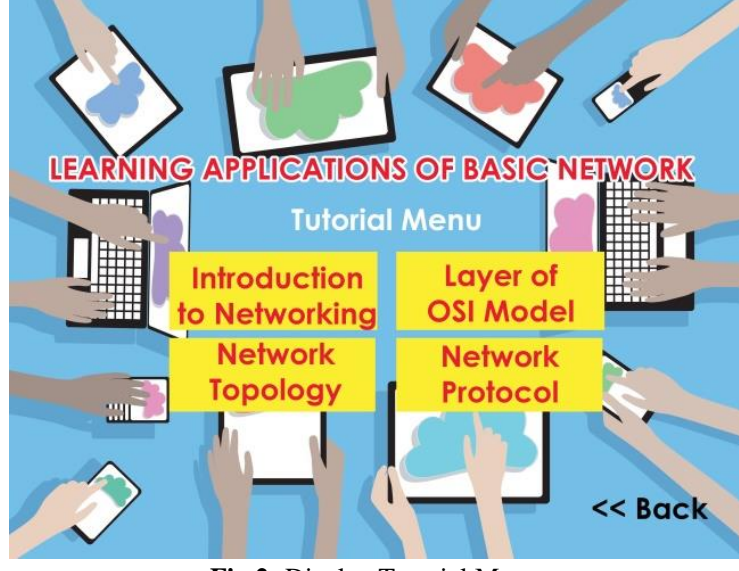

Fig.2: Display Tutorial Menu

3. Initial Menu Display Exercise

At the beginning, the exercise contains the initial word of exercise and the start button to start the exercise.

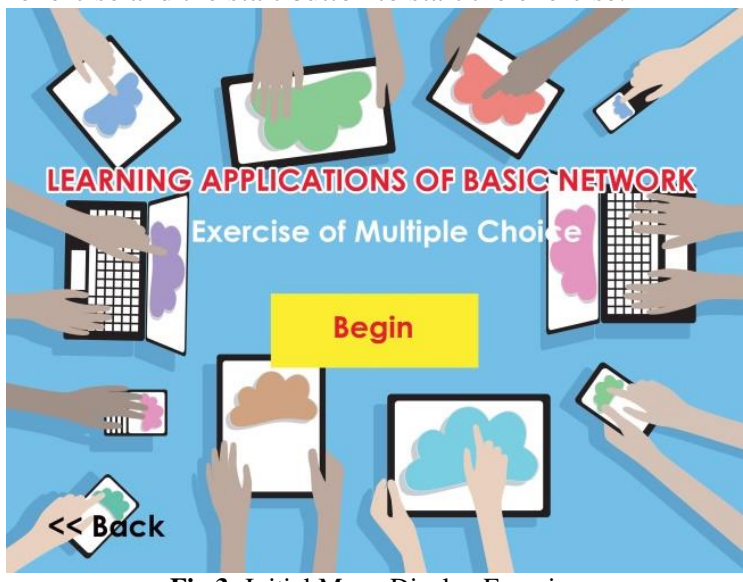

Fig.3: Initial Menu Display Exercise

At the Exercise menu there are some questions - exercise questions and also the enter key to display the answer. If the problem is true then the next problem will arise, if the answer is wrong then the next problem can not be displayed to the next problem.

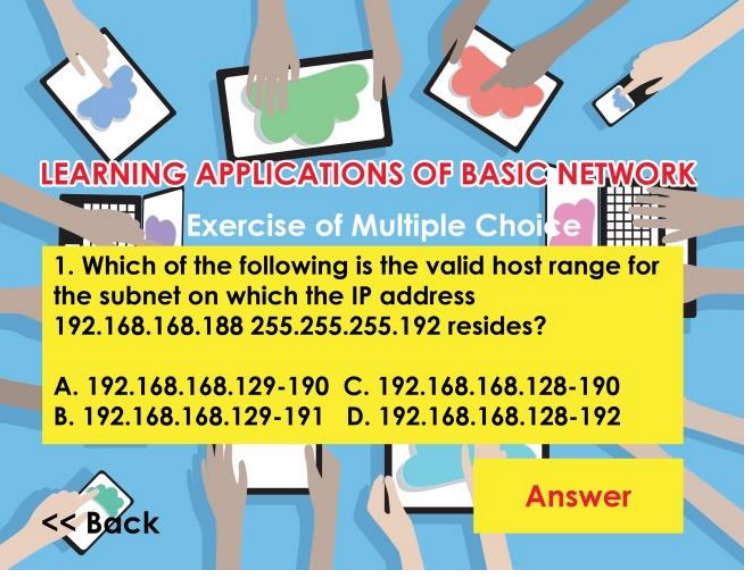

Fig.4: Menu Display Exercise

4. Display Menu Simulation

This menu displays network simulation using 2 pieces of switch / Hub in the form of animation. 


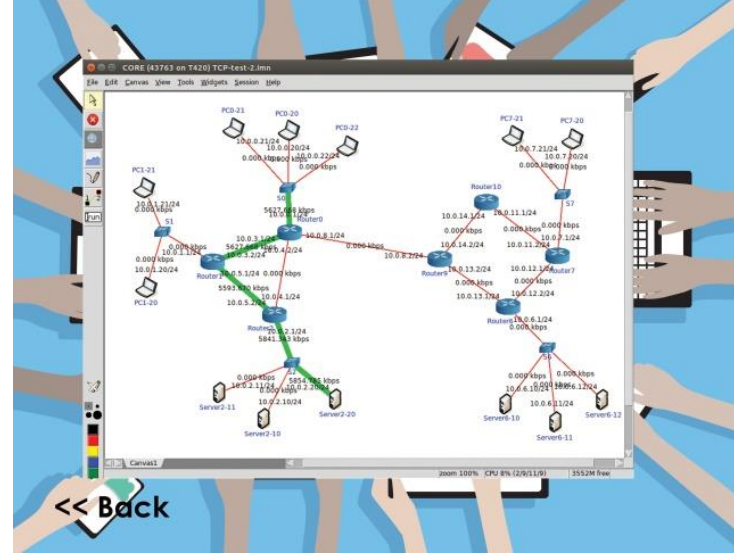

Fig.5: Display Menu Simulation

5. Games Menu Display

This menu is used to display crossword puzzle game about the basic network material that has been designed, after the click start it will appear a matter on the crosswords.

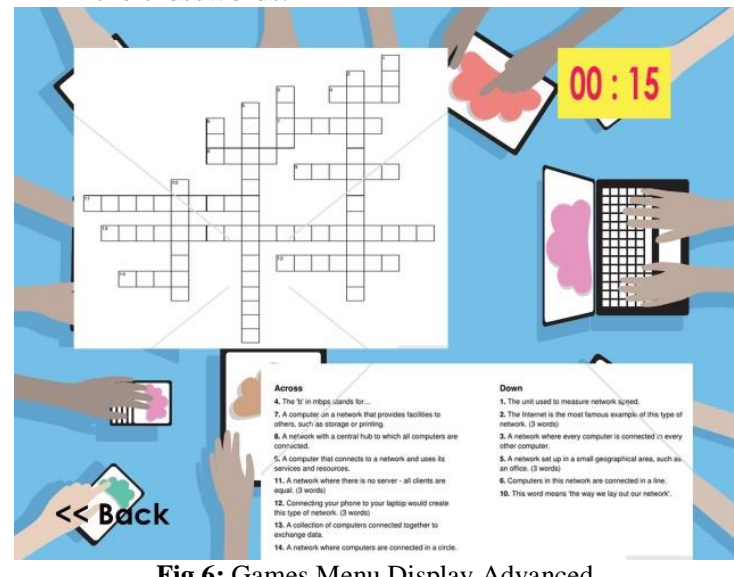

Fig.6: Games Menu Display Advanced

To test the feasibility of Interactive learning media application for this Computer Network course, it is necessary to do a questionnaire to know the user's assessment of the application. In the process of this questionnaire use questions that must be answered by the respondents. The results of the questionnaire can be seen in Table.

Table 1: Questionnaire Result

\begin{tabular}{|c|c|c|}
\hline No & Statements & Responses \\
\hline 1. & $\begin{array}{l}\text { Do you think that this application has } \\
\text { interesting design? }\end{array}$ & $\begin{array}{l}\text { Not interesting = } \\
1 \\
\text { Moderate inter- } \\
\quad \text { esting }=5 \\
\text { Interesting }=3 \\
\text { very interesting } \\
\quad=1\end{array}$ \\
\hline 2. & $\begin{array}{l}\text { Do you think that this application easily } \\
\text { accessible? }\end{array}$ & $\begin{array}{l}\text { Not easy }=0 \\
\text { Quite easy }=2 \\
\text { Easy }=3 \\
\text { Very Easy }=5\end{array}$ \\
\hline 3. & $\begin{array}{l}\text { Are you satisfied with the content provided } \\
\text { by this application? }\end{array}$ & $\begin{array}{l}\text { Not satisfied }=2 \\
\text { Moderate Satis- } \\
\text { fied }=4 \\
\text { Satisfied }=4 \\
\text { Very satisfied }=0\end{array}$ \\
\hline 4. & $\begin{array}{l}\text { Does this application facilitate your under- } \\
\text { standing of Computer Network course? }\end{array}$ & $\begin{array}{l}\text { Disagree }=0 \\
\text { Simply agree }=3 \\
\text { Agreed }=5 \\
\text { Very Agree }=2\end{array}$ \\
\hline 5. & Is this application important to you? & $\begin{array}{l}\text { Not important }=1 \\
\text { Quite important }= \\
3 \\
\text { Important }=3 \\
\text { Very important }= \\
3\end{array}$ \\
\hline
\end{tabular}

From the result of the questionnaire in Table 1 above, it can be concluded that the application of interactive learning media for Computer Network course is interesting enough in design, easy to use with the satisfied content, and the most important thing is that it can ease the students' understanding in Computer Network course.

\section{Conclusion}

Based on the result of the study, it can be concluded that the learning of basic network computer assisted, namely network introduction materials, OSI model materials in computer network, topology network materials, network protocol materials, applying the CAI is aimed to make the students interested in learning basic network materials, besides the materials can be presented by various models such as tutorial, simulation, exercises and games. By using the model, the students are hoped to increase their understanding on the presented materials equipped with the multimedia. This learning of computer network is still simple since it make use of delivering the materials in learning and the lack of the students' interest in understanding the basic network materials.

\section{References}

[1] T. Limbong, E. Napitupulu, and P. B. N. S. Sriadhi, "Learning Application Soft Skill for Facial with Computer Assisted Instruction Model," 2018.

[2] D. Napitupulu et al., "Analysis of Student Satisfaction Toward Quality of Service Facility," J. Phys. Conf. Ser., vol. 954, no. 1, 2018.

[3] J. Simarmata, "Prototype Application Multimedia Learning for Teaching Basic," vol. 7, pp. 264-266, 2018.

[4] A. R. S. Tambunan and T. M. S. Siregar, "STUDENTS'MOTIVATION IN LEARNING ENGLISH LANGUAGE (A CASE STUDY OF ELECTRICAL ENGINEERING DEPARTMENT STUDENTS)," J. English Lang. Stud., vol. 1, no. $2,2016$.

[5] N. Nasrudin, I. Agustina, A. Akrim, A. S. Ahmar, and R. Rahim, "Multimedia educational game approach for psychological conditional,” Int. J. Eng. Technol., vol. 7, no. 2.9, pp. 78-81, 2018.

[6] M. Rais, F. Aryani, A. S. Ahmar, H. Arfandi, and W. K. S. Ahmad, "Learning Media Edu-Games 'My Profession' as an Effort to Introduce Various Types of Profession in Early Childhood Education Students," in Journal of Physics: Conference Series, 2018, vol. 1028 , no. 1 , p. 12091.

[7] T. Limbong and P. D. P. Silitonga, "LOCAL DEVELOPMENT APPLICATION OF LEARNING CONTENT-BASED MULTIMEDIA BATAK TOBA SCRIPTS."

[8] S. Wahyuni, "Development of Computer Assisted Instruction ( CAI ) Based Teaching Materials in Junior High," vol. 2, no. 2, pp. 117-120, 2016.

[9] S. Sriadhi, S. Gultom, R. Restu, and J. Simarmata, "The Effect of Tutorial Multimedia on the Transformator Learning Outcomes Based on the Students ' Visual Ability The Effect of Tutorial Multimedia on the Transformator Learning Outcomes Based on the Students 'Visual Ability," IOP Conf. Ser. Mater. Sci. Eng. 384012059,2018

[10] J. Simarmata, A. Djohar, J. Purba, and E. A. Juanda, "Design of a Blended Learning Environment Based on Merrill's Principles," J. Phys. Conf. Ser., vol. 954, no. 1, 2018.

[11] J. Simarmata, Rekayasa Perangkat Lunak. Penerbit Andi, 2010.

[12] T. Limbong, P. Manullang, and E. Napitupulu, "Dikte Test Applications (IMLA) Using Computer Assisted Instruction (CAI) Model." 